\title{
Obituary for Robert J. Schreiter C.PP.S (14 December 1947-1 June 2021)
}

On 1 June 2021, the world of mission studies and theology lost one of its giants - Robert J. Schreiter, long-time Vatican II Professor of Theology at Catholic Theological Union, Chicago; past president of the American Society of Missiology; past president as well of the Catholic Theological Society of America; friend and mentor to many. We deeply mourn his loss.

Bob was a giant in every way. First, and most especially, as a human being: always available to people who sought his wisdom, open to everyone he met, totally unpretentious, deeply spiritual and reflective, a faithful friend. He also possessed a dazzling intellect. Faculty and staff at Catholic Theological Union (CTU) knew Bob as a giant of a colleague, who served as Vice-President and Academic Dean from 1977-1986 and made CTU into one of the world's most renowned theological and missiological centers. He was the founding director of the Chicago Center for Global Ministries and the Bernardin Center at CTU. He was respected in all Christian circles as a leader in theological education. His students knew him as a giant of a teacher: clear, innovative, and generous; modeling the theology and missiology he so powerfully taught. The world knew Bob as a giant of a theologian and missiologist, whose groundbreaking works like Constructing Local Theologies, The New Catholicity, and Reconciliation were read by many thousands of fellow academics, students, missionaries, and pastoral workers and were translated into some 21 languages. Bob had a towering reputation as a fascinating retreat director and as a powerful and inspiring speaker. He traveled around the world to speak - and more importantly to listen - to people who had lived through such traumas as civil war and natural disasters. Traveling to these places took faith and courage, and deeply affected him. All of this culminated in Bob's identity as an ordained member of the congregation of the Missionaries of the Precious Blood, the community into which he entered in 1961. He graduated from St. Joseph's College in Rensselaer, Indiana, with degrees in philosophy and psychology. He then studied for a doctorate in theology at the University of Nijmegen in the Netherlands with the renowned Dominican theologian Edward Schillebeeckx, and pursued post-doctoral studies at the University of Oxford. Bob served in his religious congregation in many ways. Bob Schreiter was a beloved scholar, 
mentor, and friend, and will be terribly missed. His legacy and vision will live on in the ways he enriched us all. His humanity, his brilliance, and his somewhat shy gentleness can never and will never be forgotten; and his mark on mission studies is indelible.

Stephen Bevans, SVD

Chicago, IL, USA 